\title{
Structural evidences for present-day compressive tectonics at the St. Peter and St. Paul Archipelago (Equatorial Atlantic Ocean)
}

\author{
Thomas Campos ${ }^{*}$, Kenji Motoki ${ }^{2}$, Susanna Sichel ${ }^{2}$, Leonardo Barão ${ }^{3}$, Marcia Maia ${ }^{4}$, Daniele Brunelli5, Joaquin \\ Neto $^{6}$, Thais Vargas 7 , Peter Szatimari ${ }^{8}$ and Estefan Fonseca ${ }^{2}$
}

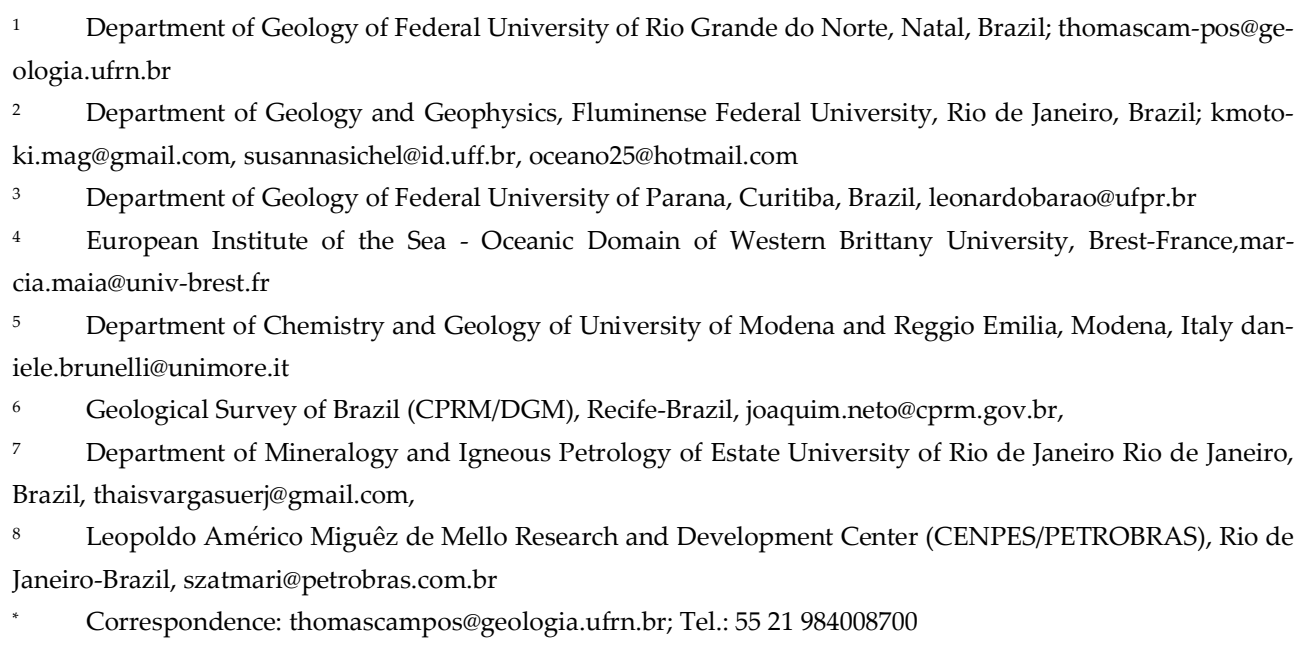

\begin{abstract}
This paper discusses the tectonics of the St. Peter and St. Paul Archipelago (SPSPA) in the Equatorial Atlantic Ocean, based on the joint-system geometry which show a North-South shortening/transpressional uplift tectonism, is active leading to exhumation of the sub-oceanic mantle. These islets are the summits of a sigmoidal submarine ridge formed by mantle ultramafic rocks. The ridge is crossed by the principal transform deformation zone of the northern transform fault of the St. Paul Multifault System. The South flank ridge exposes serpentinized mantle peridotites, while the North flank exposes strongly deformed/fractured ultramylonites, recording ductile and brittle deformation at lithospheric conditions. The SPSPA show multiple joint systems cutting mylonitic foliation of the exposed rocks, forming three main families: high-angle parallel joints of tectonic origin, serpentinization-related joints with random direction and load-release low-angle parallel joints. The tectonic joints show an average direction of $\mathrm{N} 31^{\circ} \mathrm{E}$ and $\mathrm{N} 28^{\circ} \mathrm{W}$, forming a conjugate system with a $\mathrm{N} 1^{\circ} \mathrm{W}$ compression axes, coherent with a transpressive stress field. Accordingly, the earthquakes focal mechanism close to the islets also shows N-S compression. The previously reported active uplift with an average rate of $1.5 \mathrm{~mm} /$ year and the directions of the joint system here reported agreeing with a present-day active N-S compressive field at a high angle with the direction of the transform fault.
\end{abstract}

Keywords: Tectonic joint; Pressure-ridge, Active uplift, Mantle rocks; St. Peter and St. Paul Archipelago; Equatorial Atlantic

\section{Introduction}

Massive peridotite outcrops are frequently reported along slow- and ultraslowspreading mid-ocean ridge [1-5]. Some of them are associated with particular geodynamic conditions where slices of the oceanic lithosphere are rafted to the ocean floor by compressive thrust faulting, as observed for instance in the Gorringe bank, off the Iberia 
margin [6]. Among these, the Atoba ridge is a unique feature because of its large dimensions and geodynamic context [7]. Its summit emerges at the St. Peter and St. Paul archipelago (SPSPA), located in the Equatorial Atlantic (Figure 1), and shows a rare record of extremely pervasive ductile deformation superimposed by brittle structures.

Darwin was the first geologist to unravel the singularity of SPSPA [8,9]. During the voyage of the H.M.S. Beagle (1831-36) Darwin identified the tectonic nature of these rocks; unlike the other meso-oceanic islands that are almost invariably of volcanic origin, writing in his notes: “...Is not this the first Island in the Atlantic which has been shown not to be of volcanic origin?" (Onboard notes the Beagle). Later, Renard and Murray were the first to describe as peridotite mylonite and serpentinized peridotite mylonite the rock samples collected during the Challenger Expedition (1877-76) [10-14].

The Atoba ridge is located along the Northern side of the St. Paul Transform System and is crossed by the Principal Transform Deformation Zone (PTDZ) of the northern transform fault. The St. Paul transform system is a multi-fault transform boundary, trending ENE-WSW (N80E) direction, displaying three small accreting segments, less than $20 \mathrm{~km}$ long, separated by four large offset transform faults, [7,15,16]. It offsets the MAR axes of more than $580 \mathrm{~km}$ (cumulated offset), which places it among the largest transforms of the world's mid-ocean ridges.

This paper presents new structural data from the islets of the St. Peter and St. Paul archipelago (SPSPA) agreeing with an N-S compressive stress field [17]). Our data confirm that the Atoba ridge formed after a long-standing and still active transpression, generating a positive flower structure due to the southern migration of the western ridge-transform intersection of the transform fault [7].

\section{Materials and Methods}

Mylonitic foliation and joints at SPSPA have been measured with a Brunton compass. We measured 115 mylonitic foliation and 1813 joints thus distributed: Belmonte islet: 115 mylonite foliation and 640 joints, Southeast islet: 342 joints, Northeast islet: 251 joints, Northwest islet: 244 joints, South islet: 242 joints and Coutinho rock: 94 joints (Table 1). The data were analyzed by free software GARCmB: this program uses a mixed Bingham Axial Distribution $[18,19]$ to define the stress axes $(\sigma)$.

\section{Results}

\subsection{Geological Context}

The St. Peter and St. Paul Archipelago (SPSPA) is located at $00^{\circ} 55^{\prime}$ N, 29⒛43' W, $100 \mathrm{~km}$ north to the equator in the Atlantic Ocean (Figure 1). The SPSPA is composed of 5 islets (Belmonte, Southeast, Northeast, Northwest and South) and 5 smaller rocks (Beagle, Pillar, Cambridge, Coutinho and Cabral), with a total emerged area of 13,000 $\mathrm{m}^{2}$. They represent the summit of a large sigmoidal submarine ridge, $200 \mathrm{~km}$ long, $30 \mathrm{~km}$ wide and 3,500 $\mathrm{m}$ high, named the Atoba Ridge [7] (Figures 1). 
Table 1: Descriptive statistics of joint system and mylonitic foliation of mylonite rocks from SPSPA

\begin{tabular}{|c|c|c|c|c|c|c|c|c|c|c|c|c|}
\hline \multicolumn{13}{|c|}{ Joint $(n=1813)$} \\
\hline & \multicolumn{6}{|c|}{ Strike } & \multicolumn{6}{|c|}{ Dip } \\
\hline Islet & Max & Min & Mod & Med & Mea & SD & Max & Min & Mod & Med & Mea & SD \\
\hline Belmonte & 358 & 0 & 60 & 147 & 169 & 3.9 & 90. & 5 & 90 & 60 & 58 & 0.8 \\
\hline Northwest & 346 & 1 & 146 & 157 & 168 & 7.1 & 90 & 15 & 70 & 65 & 60 & 1.3 \\
\hline Northeast & 357 & 15 & 125 & 127 & 140 & 4.9 & 90 & 3 & 80 & 60 & 57 & 1.2 \\
\hline Southeast & 360 & 5 & 100 & 170 & 185 & 9.8 & 90 & 6 & 80 & 60 & 57 & 1.0 \\
\hline South & 355 & 5 & 220 & 195 & 179 & 9.7 & 90 & 5 & 55 & 60 & 60 & 2.0 \\
\hline Coutinho & 247 & 2 & 135 & 133 & 142 & 9.8 & 85 & 13 & 80 & 64 & 58 & 2.0 \\
\hline \multicolumn{13}{|c|}{ Mylonitic Foliation $(\mathbf{n}=115)$} \\
\hline & \multicolumn{6}{|c|}{ Strike } & \multicolumn{6}{|c|}{ Dip } \\
\hline Islet & Max & Min & Mod & Med & Mea & SD & $\operatorname{Max}$ & Min & Mod & Med & Mea & SD \\
\hline Belmonte & 355 & 0 & 300 & 285 & 198 & 6.9 & 90 & 8 & 75 & 50 & 50 & 1.1 \\
\hline
\end{tabular}

Max: maximum, Min: minimum, Mod: mode, Med: median, Mea: mean, SD: standard deviation

The SPSPA is formed by abyssal peridotites uplifted tectonically in an extensively sheared and thrust-faulted transverse ridge during a dextral strike-slip movement with multiple-stages of transpressional and transtensional uplifting [7,16,17]. Deformation processes recorded by these rocks extend over the ductile/brittle rheological transition, starting at high temperature at upper mantle conditions and recording an intense anhydrous ultramylonitization [20]. Deformation in the brittle regime is recorded by a joint system concordant initially with the orientation of mylonitic foliations. Cracking allowed fluid circulation and started the serpentinization of peridotite ultramylonite (Figures 2 and 3 ).

The Southeast islet shows a peculiar outcrop because it is partly formed by layered ultramafic mylonites, composed by $\mathrm{mm}$ to $\mathrm{cm}$ thick alternate layers of mylonitized kaersutite and peridotite. They display an undulated contact possibly suggesting a non-tectonic origin [19]. The kaersutite layer may derive by trapping and crystallization of an alkaline fluid compositionally akin to that percolating in the ambient peridotite [21]. This islet shows a relatively thick sedimentary cover $(\approx 4 \mathrm{~m})$, named St. Paul and St. Peter Formation of Neogene age and this sedimentary cover is constituted of two units of calcarenite-conglomerate in stratigraphic discordance associated with the tilting of an old bay floor driven by earthquakes [17].

The studied area shows a particular stress field [22,23]. While most of the events have strike-slip focal mechanisms, a few earthquakes show an NNW-SSE compressive mechanism (Figure 4). These events are located on the south flank of the Atoba Ridge, on a thrust fault identified by [7]. The earthquakes indicate that the main tectonic stresses are generated by a dextral strike-slip displacement, coherent with the motion direction of St. Paul transform fault and secondary compressive stress oriented to NNWSSE.

The single islets show a relatively differential movement and independent behavior, as demonstrated by their fossil record, which shows different ages among them of about 10.000 yr. (C-14 dating), at the current level of marine surface abrasion [17]. Fossils from the Belmonte islet show ages varying from 100 to 6 kyr. B.P., while in the Southeast islet the fossil ages vary between $16 \mathrm{kyr}$. to $46 \mathrm{kyr}$. B.P. [17,24] . SPSPA shows an overall minimum average uplift rate of $1.5 \mathrm{~mm} / \mathrm{yr}$ and a maximum uplift rate of $3.0 \mathrm{~mm} / \mathrm{yr}$. at recent times $[17,24,25]$. 


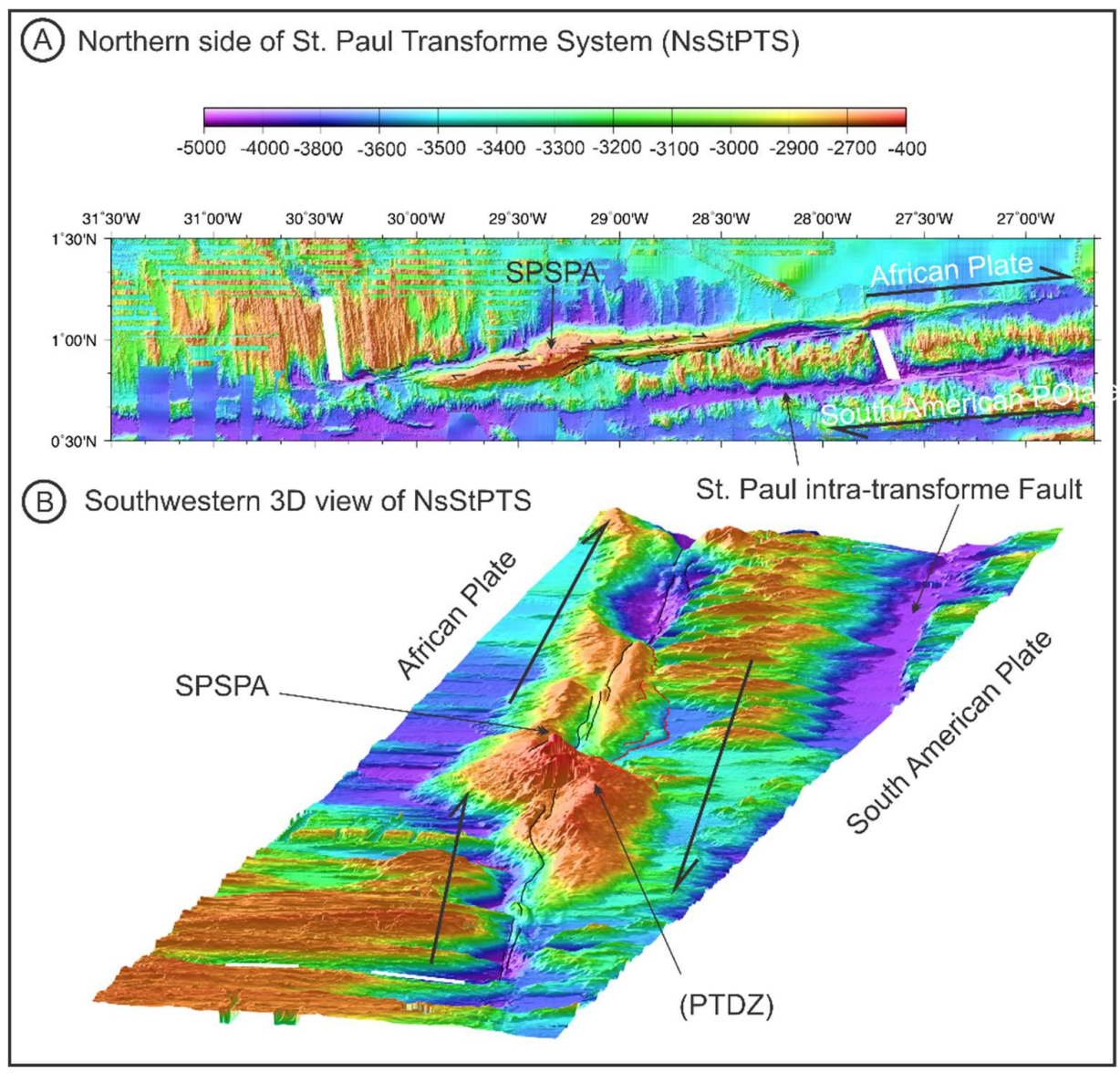

Figure 1: Location map of Saint Peter and Saint Paul Archipelago and Saint Paul Transform Fracture Zone, Equatorial Atlantic Ocean and morphostructure of the Northern side of St Paul shear zone [7]. A) shaded multibeam bathymetry of Central transpressive (CTZ) zone displaying stepovers of the transform fault on either side of St Peter and St Paul Archipelago. The Atoba Ridge is located at the central step. The base of the south flank of the CTZ displays a series of thrust faults. B) Southwestern 3D view of CTZ. Thick black lines: present-day active transform faults, with the semi-arrows showing the plate motions direction. The black tick lines: thrust faults. The white lines: present-day spreading axes. PTDZ: Principal Transform Deformation Zone. Plate boundary [7]. 


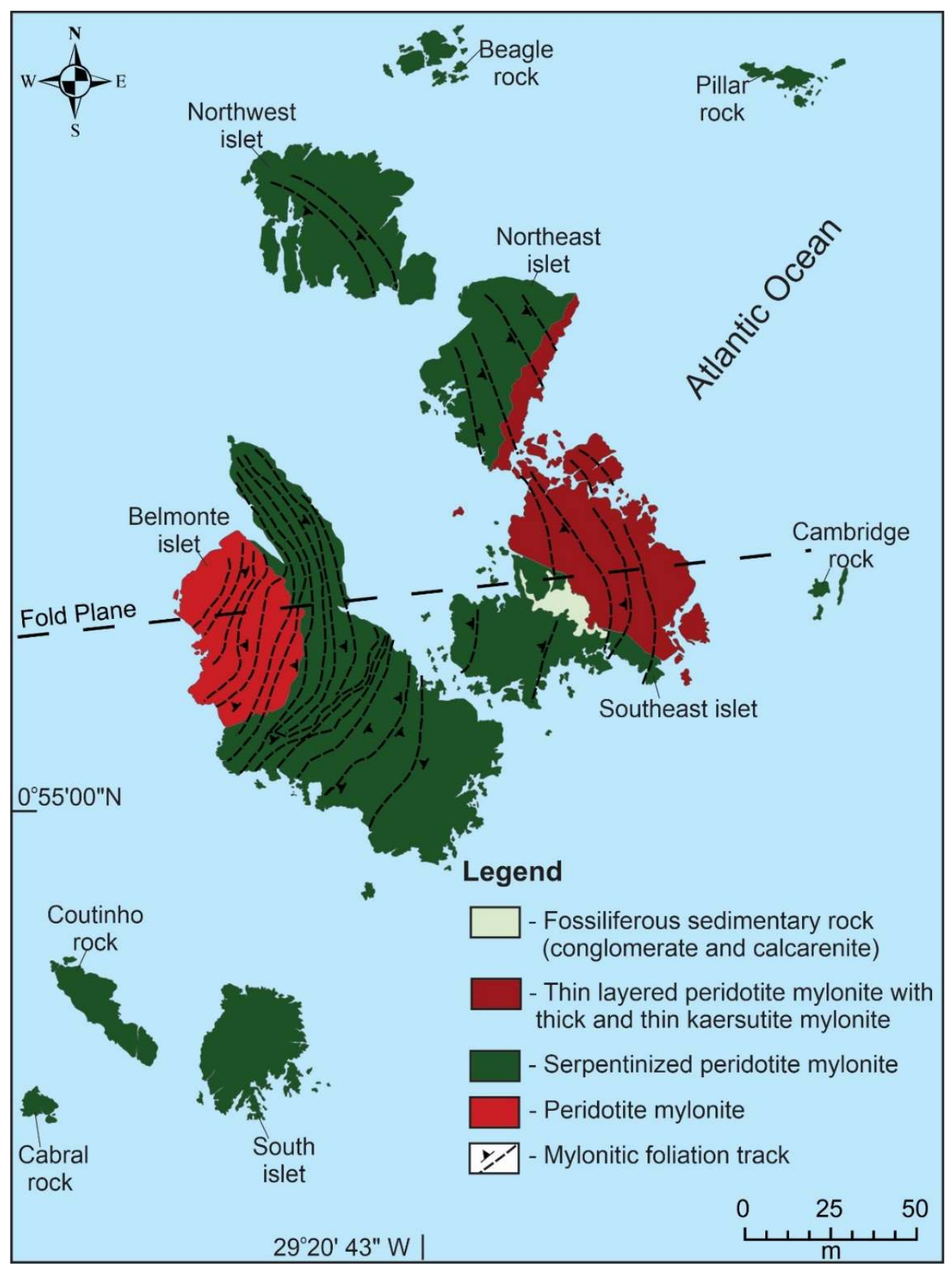

Figure 2: Geologic map of St. Peter and St. Paul Archipelago, Equatorial Atlantic Ocean according [17]. The mylonite foliation according [20]. 


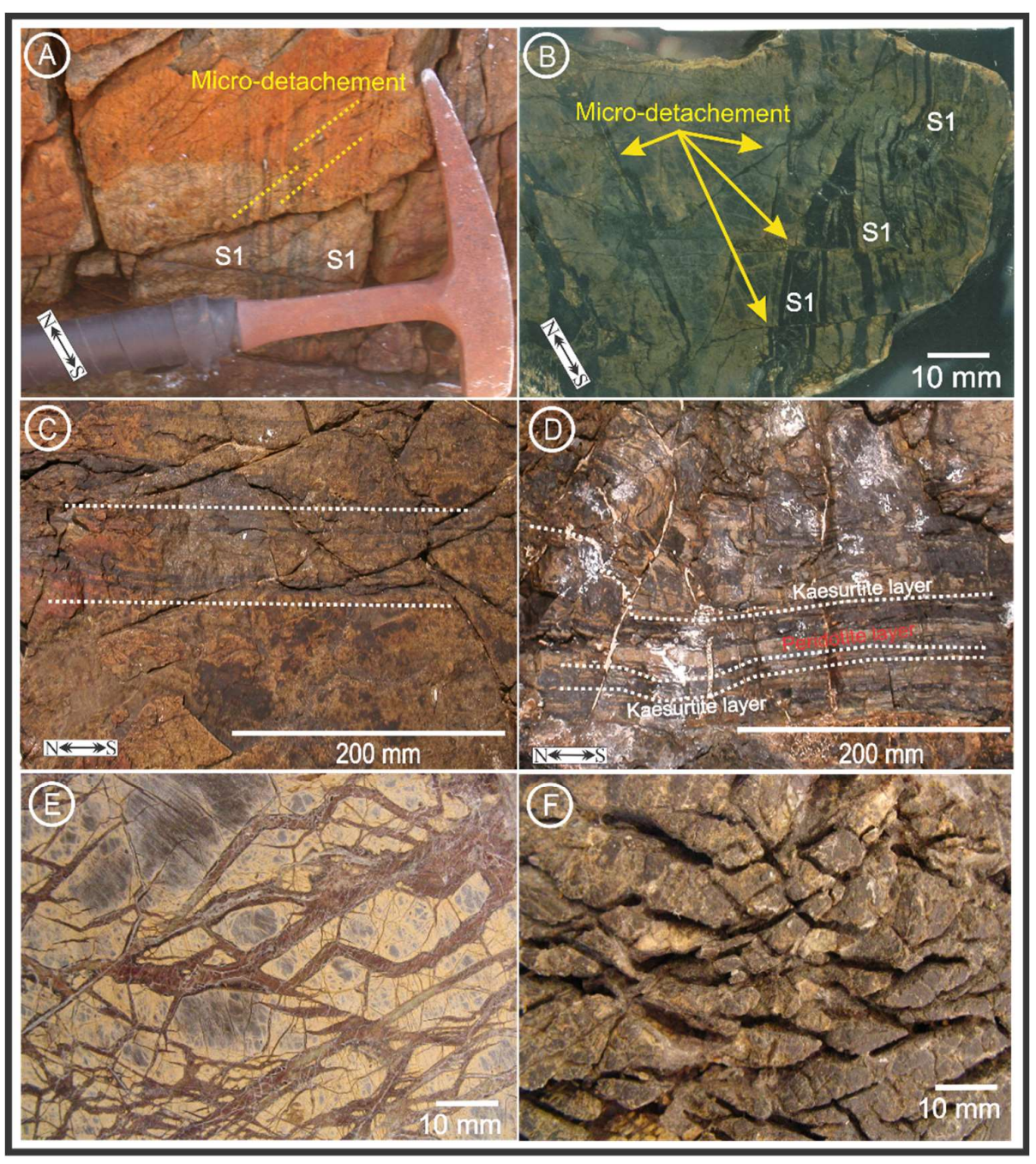

Figure 3: Photography of hand samples: A) Peridotite mylonite showing parallel S1 mylonite foliation and micro-detachment (S2); B) Polished surface of peridotite mylonite showing folded mylonite foliation cut by micro-detachments. C) Parallel layered kaersutite-peridotite mylonite; D) Folded and fractured layered kaersutite-peridotite mylonite; E) Polished surface of a serpentinized peridotite ultramylonite; F) Outer surface of the sample in Figure 4E, where the joints are highlighted by seawater leaching. A) and B) fresh peridotite from Belmonte islet; C) and D) Fresh mylonite from Southeast islet; E) and $\mathrm{F}$ ) serpentinized peridotite ultramylonite from Belmonte islet. 


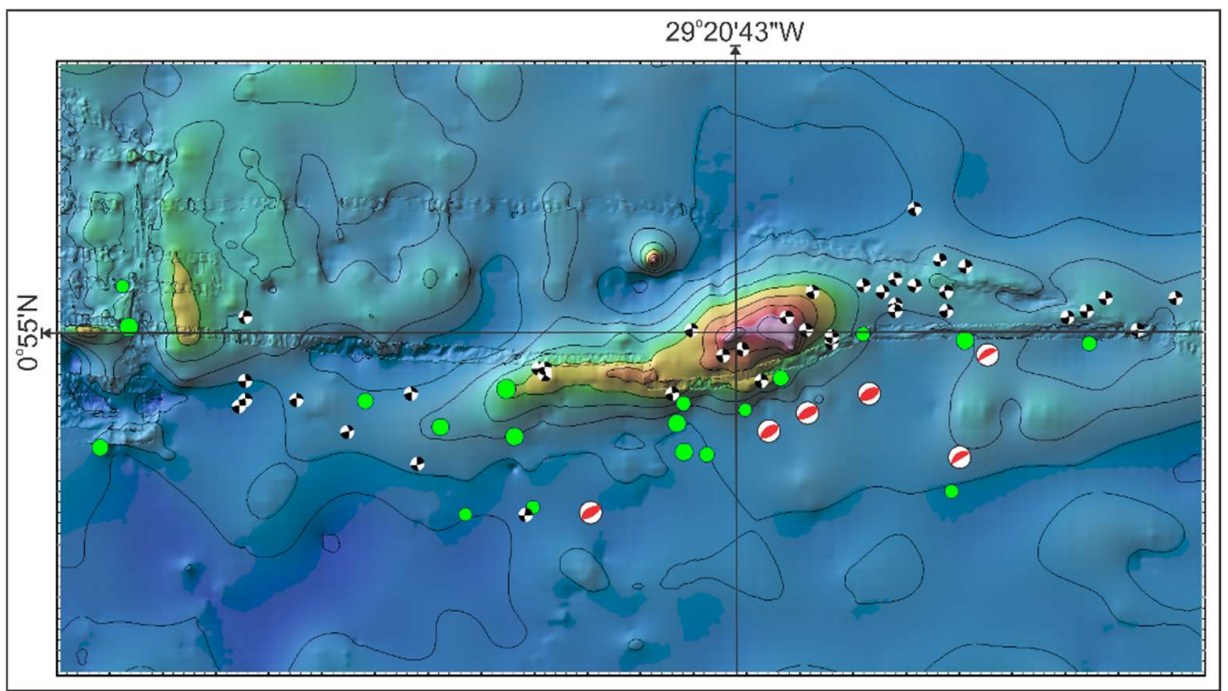

Figure 4: Focal mechanism and the epicenter of the seismic events recorded from 1971 to 2018 [22,26]. Highlighted red beach-ball indicates a compressive mechanism. Green circle: Epicenter $<50 \mathrm{~km}$ of deep and proportionally larger circle diameter than $\mathrm{M} \geq 5.0$.

The regional/scale uplift of a dense mantle block poses a tectonic problem because its elevation requires a significant, long lasting, compressive tectonics acting right over the loci of a pure strike-slip transform-related domain. This conundrum was solved by demonstrating that a compressive field is acting steadily since $11 \mathrm{Ma}$ along on the Atoba ridge because of the progressive southward propagation of the Mid Atlantic Ridge axis to the West [7]. This axis propagates due to the thermal influence of the Sierra Leone hotspot $[27,28]$, which results in an enhanced magma supply at the MAR segment and in a modified lithospheric thermal structure (Figure 1). The local transpressive stress is witnessed by the formation of a series of oblique step-overs and restraining bends located along the northern fault of the St. Paul transform system. The main step-over, beneath the Atoba ridge, acts as a resistant pivot point accumulating the maximum transpressive stress along the northern transform fault leading to the elevation of the seafloor by more than $3 \mathrm{~km}$ passing over the sea level [7].

Lineament directions at Lower-hemisphere, equal-area stereo-plot projections show that interpreted indicating two general directions at $\mathrm{N} 41^{\circ} \mathrm{W}$ and $\mathrm{N} 34^{\circ} \mathrm{E}$ and the straight dihedral-angle method defines the following compression axes $\sigma_{1} 365.5 / 90$ and $\sigma_{3}$ $86.5 / 90$. The current coastline, together with the observed lineaments (Figures 2 and 5) and SPSPA position within St Paul transform system can be correlated with the Riedel diagram (Figure 6). Where we can see a coherent tension pattern, which establishes a tension axes directions close to N-S for $\sigma_{1}$ and E-W for $\sigma_{3}$.

\subsubsection{Joint typologies}

Joints (or extensional fracture system), are separation planes in which there is no detectable shear displacement. The two walls of these tiny gaps are generally in close contact and match one each other. They may result from regional tectonic strain, either due to compressive stresses, folding and faults, or by the release of internal stress during uplifting or cooling. High fluid pressures may also result in the formation of a joint system. The aperture of a joint can be open or occluded by mineral cement $[29,30,31]$.

The rocks from St. Peter and St. Paul Archipelago show a primary mylonitic structure and four different joint types. Their sequential order can be defined on the outcrop following the relative intersection patterns. 
In a temporal frame, the overall rock deformation can be summarized as follow: a) subvertical joint system cutting the mylonitic foliation of the mantle derived ultramafic rocks (Figures 7A and $3 \mathrm{~A}$ and $3 \mathrm{~B}$ ); $\mathrm{c}$ ) randomly oriented joints due to serpentinization (Figure 3E and F); b) sub-vertical joints of tectonic origin (Figure 7B); d) open joints, due to falling/tilting block, filled by sedimentary carbonate-Fe oxides (Figure 7C); e) open load-release sub-horizontal joints filled by precipitate carbonate (Figure 7D).

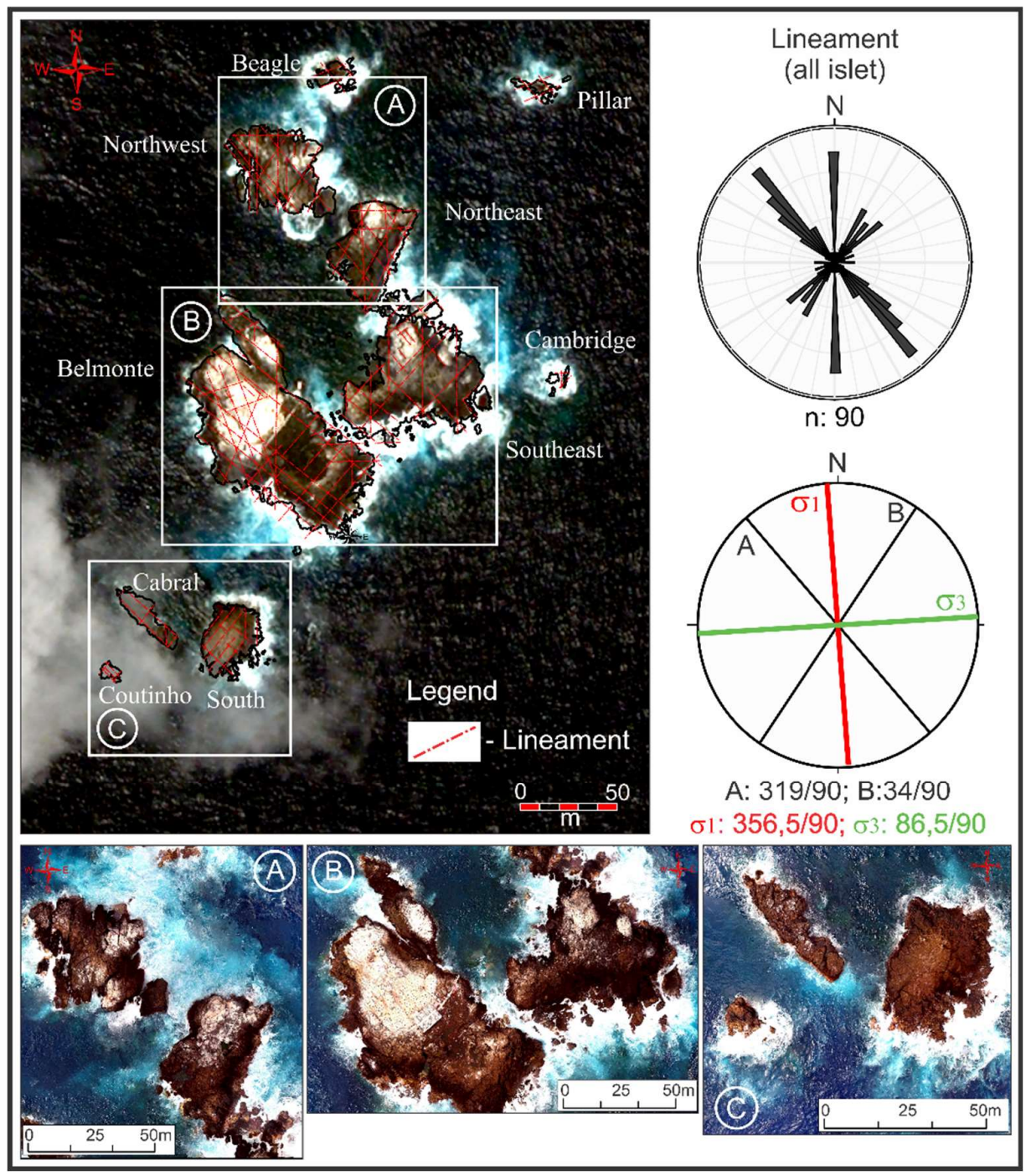

Figure 5: QuicBird satellite and Drone imagery used for lineament interpretation and Lower-hemisphere, equal-area stereo-plot and rose diagrams for lineament interpretation in the St. Peter and St. Paul Archipelago, Equatorial Atlantic. Red dashed line: lineament. 


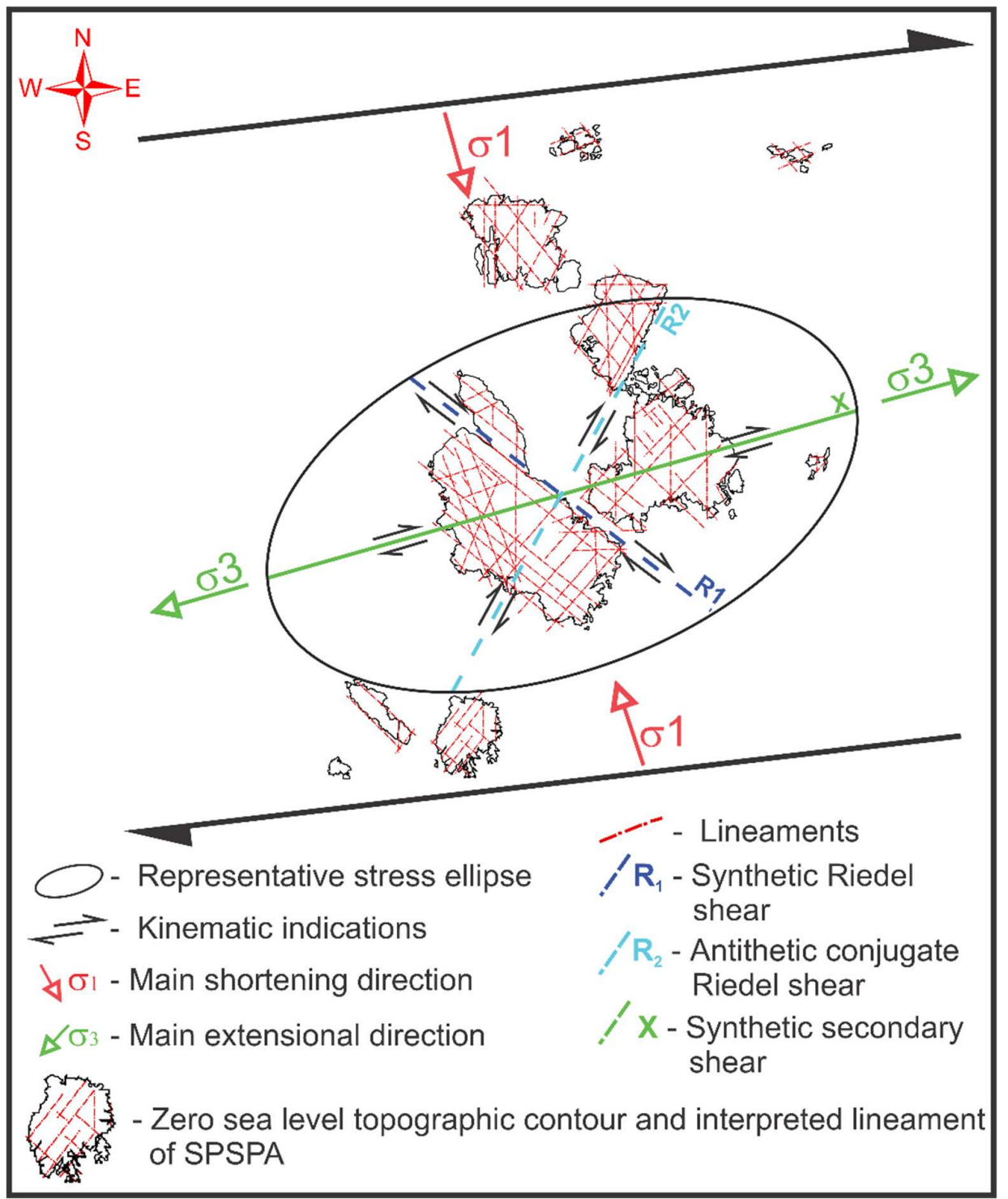

Figure 6: Riedel-type schematic constructed using major lineament trends identified through satellite/drone imagery and stereographic projections at shoreline contour of the islands from SPSPA (Figure 4). The shear black arrow is in a similar context to that occurring in the St. Paul Transform Fracture System.

The first set of joints can be attributed to late deformation phases in the ductile to brittle transition [20]. The first set of structures is attributed to the folded mylonitic foliation shown in Figure 7A. It's a typical evolution from folding to micro faulting along the S2 fold plane. Being the displacement extremely reduced we consider here these fractures along with the other joint systems. The transitional passage between the stage of ductile-brittle transition marks semi-brittle conditions. Allowing the formation and stabilization of the serpentinization process [20].

The serpentinization network formatted in semi-brittle to brittle conditions overprints the mylonite foliation; serpentinization progresses along extensional joints crosscutting the high- $T$ foliation. Volume expansion due to serpentinization generates randomly oriented fractures similar to kernel structures (Figure 3E and F) and four serpentine phases related to the transition to a semi-brittle to brittle settings [20]. 
The joints filled by calcarenite and iron oxides-hydroxides were interpreted by $[17,32]$ as pre-existing open joints formed by rock-slide flexure and filled with sedimentary biologic and chemical carbonates, sometimes mixed with sandstone. They are either sub-vertical or sub-horizontal, and many joints show undulating curvatures (Figure 7C and B). Sedimentary fill occurs in all open joints and shows a width variable, from a few millimeters to more than $20 \mathrm{~cm}$. The carbonation phase marks the final deformation stage marking the complete exhumation of the body and the formation of fractures and fault planes filled by carbonates in the brittle context [20].

Load-release joints are formed by removal of surface rocks wave erosion and gravitate slumping along the flanks of the rising ridge (Figure 7D). They are sub-horizontal showing a gentle curvature. Along these joints, gravitational slides of the upper blocks are sometimes observed, they cut all serpentinization joints.

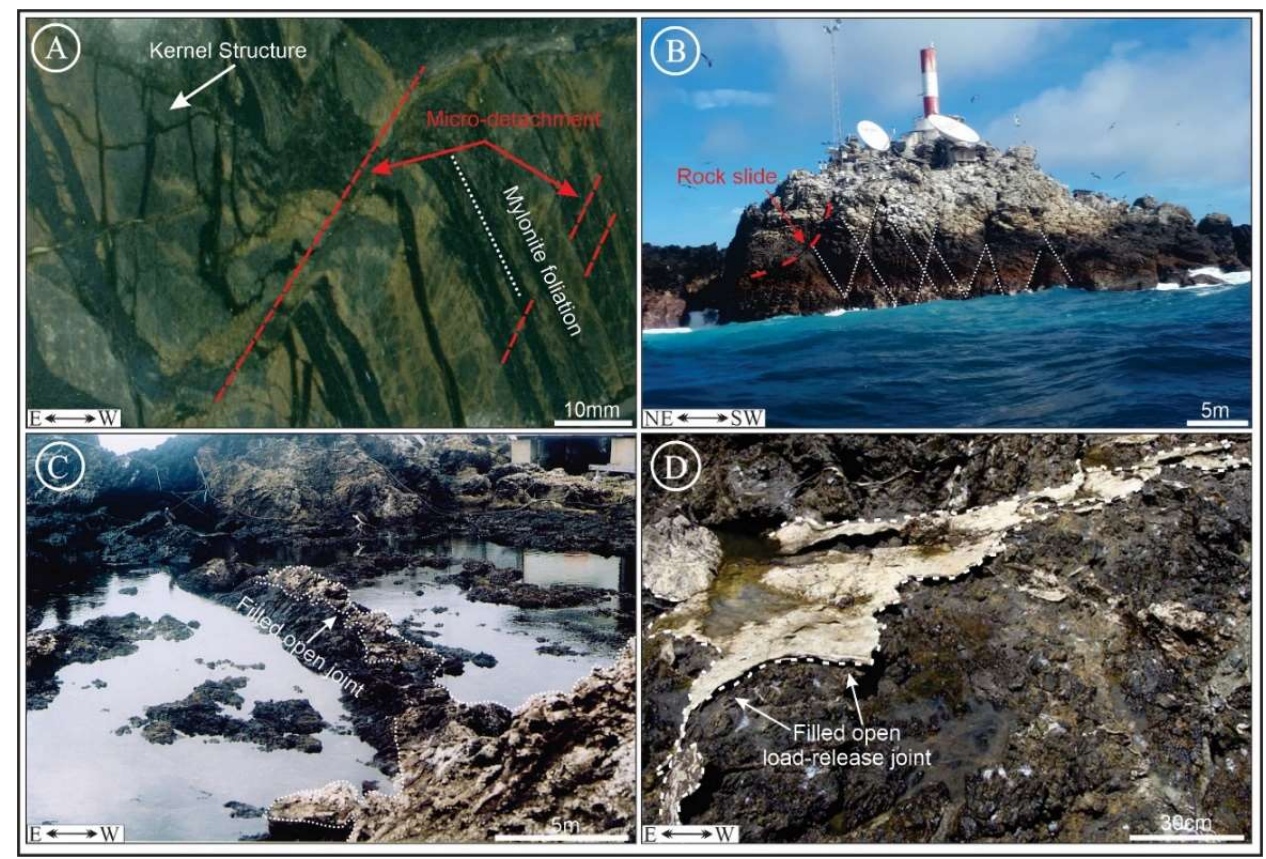

Figure 7: Mylonitic foliation and different types of joints observed at the Saint Peter and Saint Paul Archipelago: A) Polished peridotite mylonite hand samples from Belmonte islet showing parallel and folded S1 mylonitic foliation and micro-detachment (S2); B) Tectonic joints with high-angle (white arrows) at the Belmonte Islet; C) Open joints filled by calcarenite and iron oxides-hydroxides (white arrows) at the Belmonte Islet; D) Open load-release filled by precipitated carbonate (white arrows) at the Southeast Islet.

\subsection{The high-T mylonitic foliation}

The mylonitic fabric characterizing all SPSPA rocks predates the joint system described in the next paragraph. The high degree of mylonitization recorded by these rocks (prevalence of ultramylonites) requires intensely focused shearing in the ductile regime and represents the oldest structural event recorded by the SPSPA rocks [20]. The orientation of the mylonitic foliation reveals that rock domains around the Belmonte islands have suffered important local rotations. However, only a few measures, statistically not significant, have been carried out in these islets because not easily readable. In turn, on Belmonte islet the ultramylonite shows one primary foliation S1 oriented to $33^{\circ} / 75$ and a secondary foliation S2 $\left(322^{\circ} / 29\right)$ (Table 1 and Figure 8). The foliation S1 is gently folded belong to the islands of the SPSPA (Figures 2 and 8), foliation tends to vary in NE-SW to 
NW-SW directions (Figure 8). This regional fold observed along the islands has a direction axis approximating E-W, parallel to the direction of St. Paul Shear Zone (Figure 1).

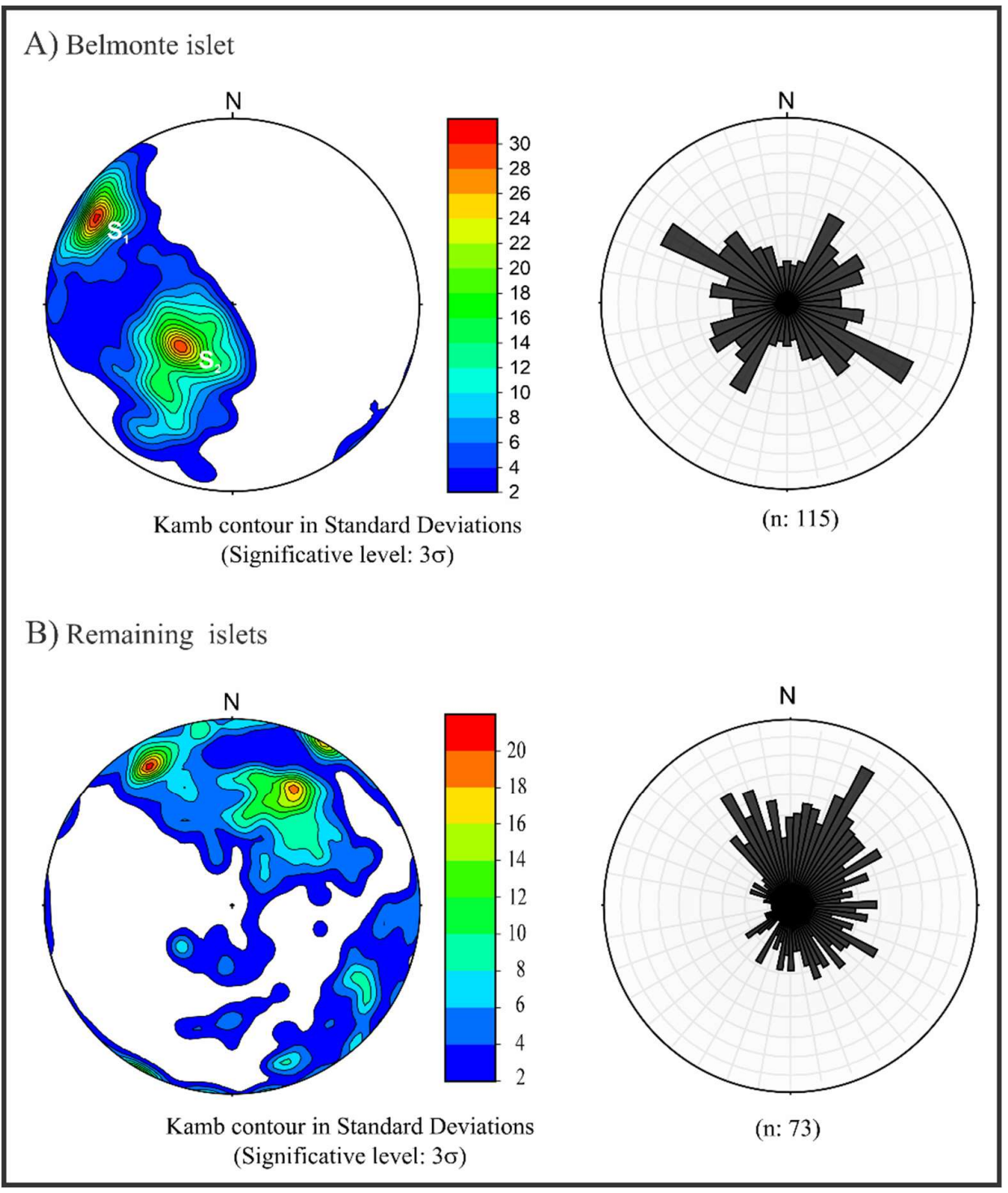

Figure 8: Lower-hemisphere, equal-area stereo-plot and rose diagrams of the mylonitic foliation from the St. Peter and St. Paul Archipelago: A) Belmonte islet: S1 oriented to $33^{\circ} / 75$ and S2 to $322^{\circ} / 29$; B) Remaining islets: S1 oriented to $330^{\circ} / 14$ and S2 to $279^{\circ} / 3$.

The microscale analysis clearly shows that the observed S1 marking the orientation of olivine, orthopyroxene, spinel and amphiboles. This structure is locally overprinted by folding and micro-detachment (Figure 9A). Fold axis and micro-detachment coherently shows the presence of a compressive stage S2 acting over the ductile to brittle transition as attested by the evolution from ductile folding to kink banding and micro faulting (Figure 9B to 9D). This stage can be related to the thrusting inferred by geophysical observations affecting the Atoba ridge [7]. 


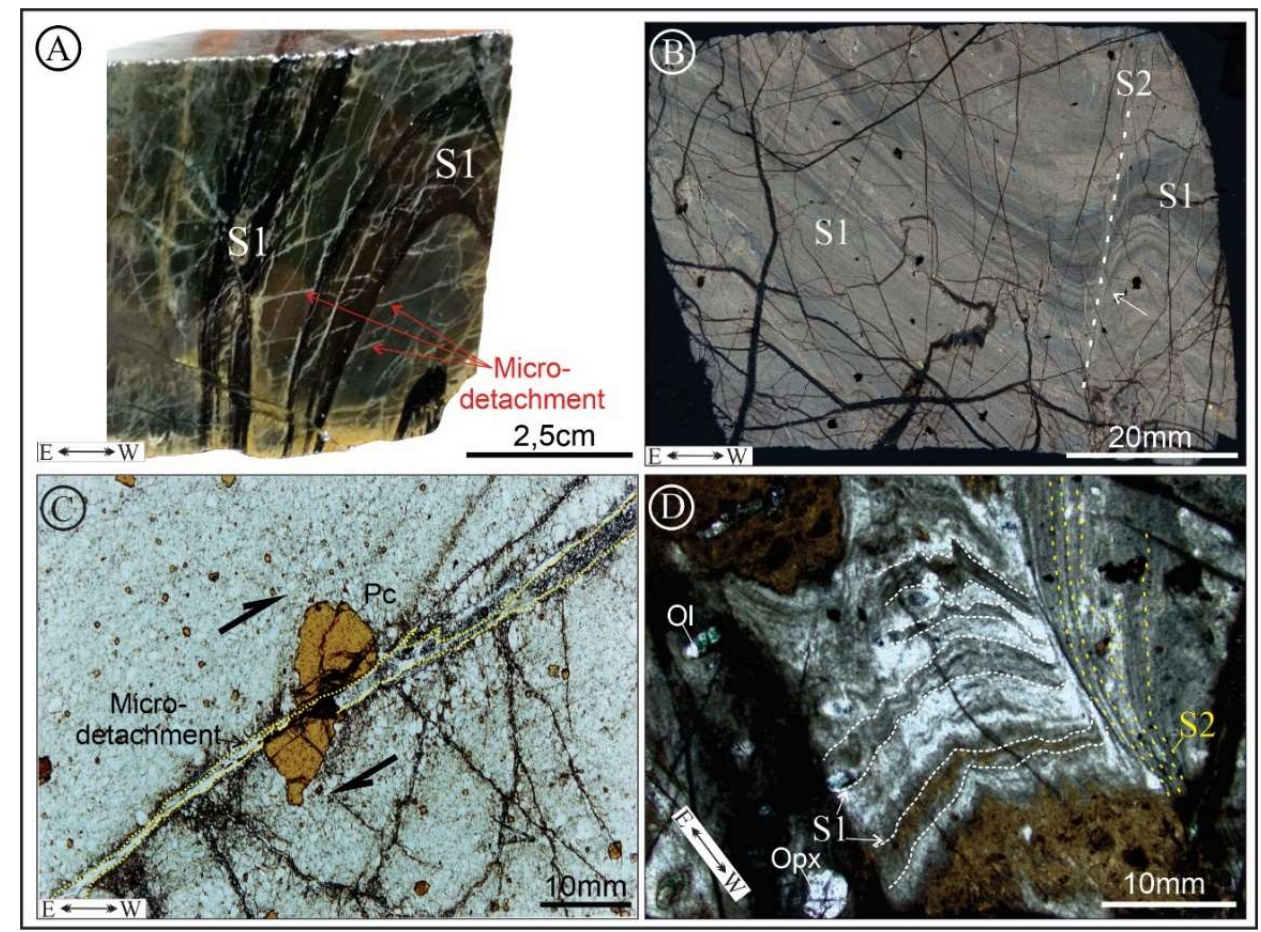

Figure 9: A) Mylonite peridotite showing fold S1 mylonite foliation and micro-detachment (S2) from Belmonte islet; B) Mylonite peridotite showing fold on S1 mylonite foliation and S2 from Belmonte islet (plain light); C) Photomicrograph of a picotite porphyroclast cut by micro-detachment showing dextral reject from Belmonte islet (plain light); D) Photomicrograph of peridotite showing some kink-band on S1 mylonite foliation from Northeast islet, witnessing the presence of multiple deformation phases (S2) (polarized). Ol: Olivine; Pc: Picotite; Opx: Orthopyroxene.

\subsection{Conjugate joint system}

Conjugate shear fracture patterns are common in all kinds of materials and result from the brittle response to a stress field. The orientation of the joint surfaces has a strict correlation with the orientation of the neotectonic stress field. The principal stress field directions can thus be determined by statistical treatment of joint orientation data $[29,30,31,32,33,34,35,36,37,38,39]$.

Laboratory experiments have shown that the joints are distributed symmetrically concerning the main stresses $\left(\sigma_{1}\right)$, based on the "Coulomb fracture criterion", which allows them to be used as tectonic indicators of regional stress $\left(\sigma_{1}>\sigma_{2}>\sigma_{3}\right)$, [40]. The directions of the stress components bisect the dihedral angles between the measured plane directions: the bisector of the obtuse angle between the poles of conjugate plans marks the $\sigma_{1}$ axes; concomitantly $\sigma_{3}$ bisects the acute angle and $\sigma_{2}$ corresponds to the pole of the intersection of conjugate fracture planes.

Pole orientation of all joint types are plotted as density map using the lower-hemisphere, equal-area stereo-plot and a rose diagram in Figure 10, data are reported in Table 1 . In these diagrams, $\mathrm{A} 1, \mathrm{~B} 1$ and $\mathrm{C} 1$ points indicate the highest density pole (trend/plunge: $242^{\circ} / 09^{\circ} ; 300^{\circ} / 33^{\circ} ; 136^{\circ} / 55^{\circ}$ ) and the denser plane data concentration (Strike/Dip: 332\%/80; 31\%/57; 225\%/37\%). The joints A1 e B1 are sub-vertical and cross-line in a $138.6^{\circ} / 55.6^{\circ}$, forming a conjugate shear system. The direct dihedral-angle method 
gives a compression axes $\sigma_{1}$ at $358.4^{\circ} / 6.36^{\circ}$ and $\sigma_{3}$ at $99.4^{\circ} / 66.6$, which is similar to the axes direction inferred based on the interpreted lineaments (Figures 6 and 10). The C1 point is considered an extensional joint (Figure 10)

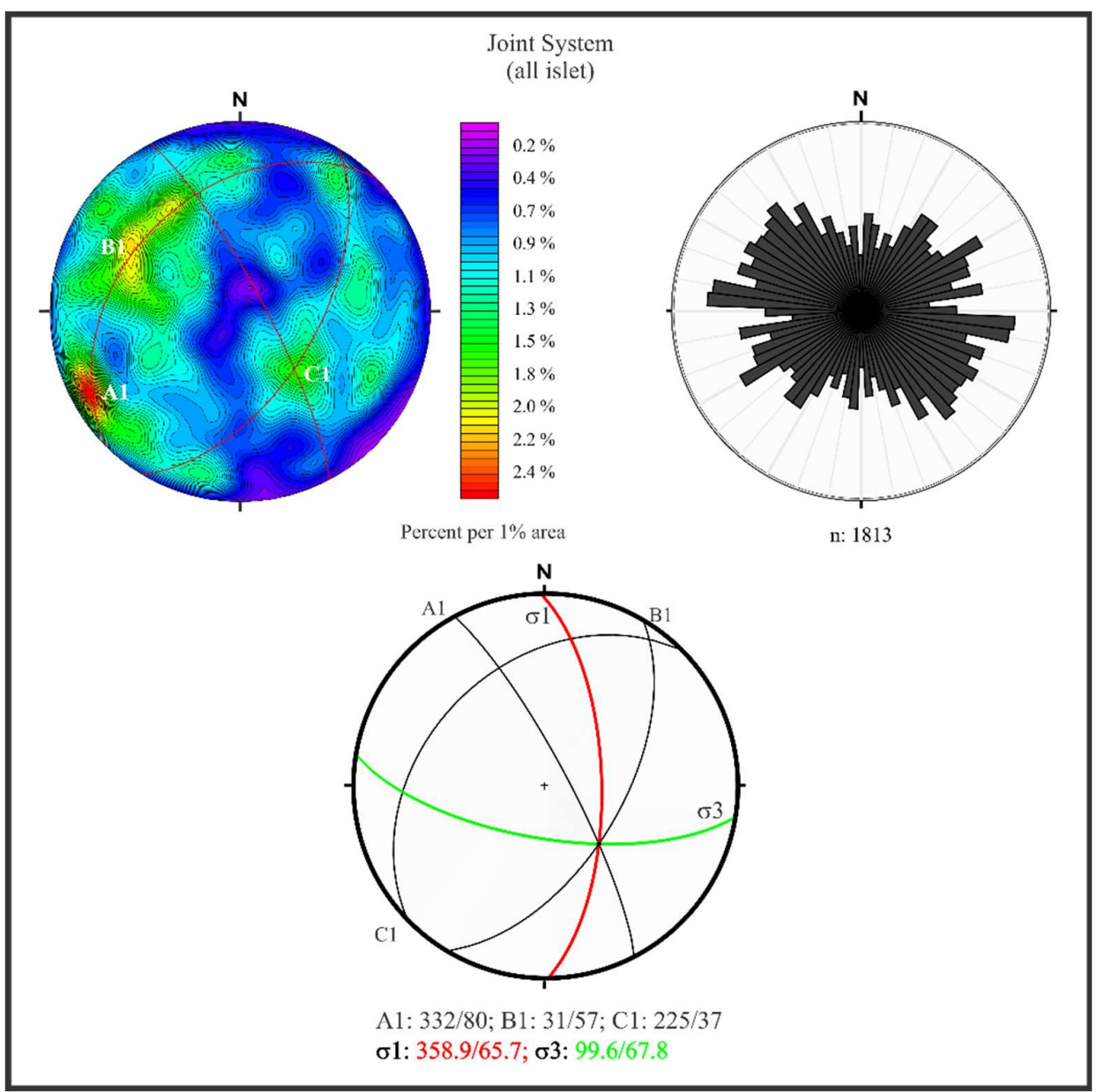

Figure 10: Lower-hemisphere, equal-area stereo-plot and rose diagrams of the joint system from the St. Peter and St. Paul Archipelago (n: 1,813): A1 and B1 are conjugate shear joints; $\mathrm{C} 1$ are extension joint; $\sigma_{1}$ and $\sigma_{3}$ stress axes.

\section{Discussion}

\subsection{Far-field versus local components}

The individual islets show different joint distribution (Table 1 and Figure 11), but the locations of the denser data concentration are similar and their $\sigma_{1}$ is sub-vertical and range from $4.1^{\circ} / 7.9^{\circ}$ (Northwest islet) to $177.5^{\circ} / 82.8^{\circ}$ (Coutinho islet). The cumulative plot in Figure 11 shows an average of $\sigma_{1}$ oriented $\sim$ N-S $\left(358^{\circ}\right)$. However, by excluding the Northwest islet, all others show a $\sigma_{1}$ direction much coherent with the expected compressive component in a dextral shear and according to the Riedel formalism (Figure $6)$. The striking coherence with the expected and measured Riedel structures at the outcrop scale (Figures 5 and 6) suggests that the main factor controlling the observed fractures is related to the far-field stress regime deriving from the regional dextral strike-slip of the transform fault. Seismic events with compressional focal mechanisms reported in 
Figure 4 are coherent with the direction of the joint system and further supporting the presence of active $\sim \mathrm{N}-\mathrm{S}$ oriented compression.

The strike/dip variability and distribution among individual islets of SPSPA suggest the presence of local geological factors superposed to the far-field common stressdriven deformation at the scale of the archipelago (Figure 8). This effect is readable for the Northeast, Cabral and part of Southeast islets, which show different strike/dip from those of adjacent areas (Figures 11 and 12).

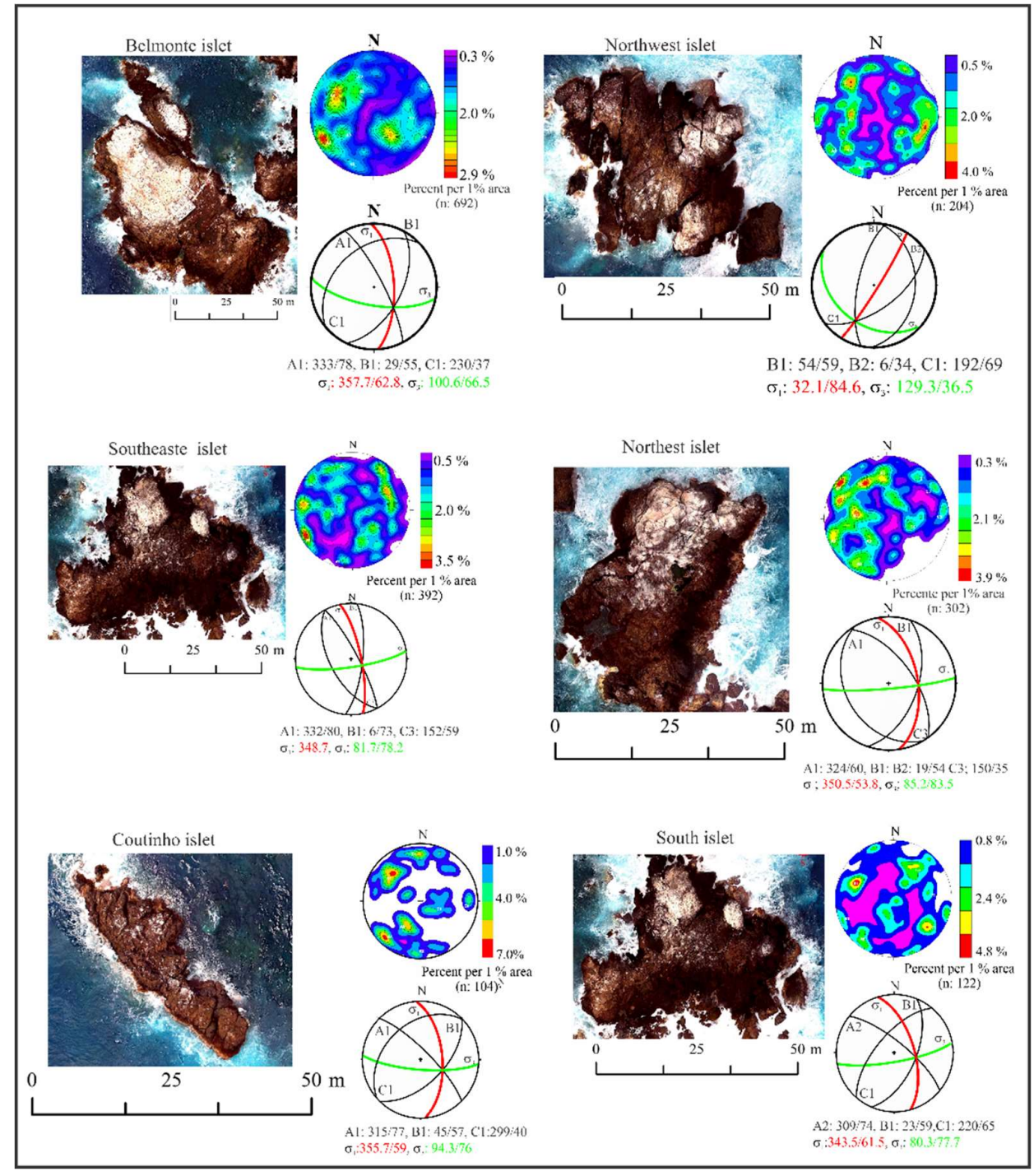

Figure 11: Lower-hemisphere, equal-area stereo-plot and rose diagrams of the joint system by islet from St. Peter and St. Paul Archipelago (n: 1813): A1 and B1 are conjugate shear joints; $\mathrm{C} 1$ are extension joint.

The deformation sequence of these rocks has been described in detail by [20], which pointed out the progressive extent of fluid-rock interaction during the different deformation stages. The oldest deformation stage is here represented by the S1 mylonitic foliation coherently exposed in the Belmonte Island (Figure 2). Mylonitic fabric in such pervasively deformed rocks is expected to be sub-parallel to the shear direction. The Atoba 
ridge grows directly over the transform fault deformation zone that is possibly responsible for the development of the high-T mylonitic deformation at depth.

Shearing along the transform fault is generated by the strike-slip dextral shear field-oriented approximately E-W (N80E). This movement should result in a sub-vertical deformation plane in the ductile region. The observed S1 mylonitic direction on Belmonte is sub-vertical but oriented at a high angle to the strike-slip direction $\left(33^{\circ} / 75\right)$ suggesting a significant rotation concerning to the direction of the main shear stress. However, the regional dextral shear only allows clockwise rotations, hence a minimum rotation of 133 degrees clockwise. The extreme rotation is allowed by the sub-vertical direction of the foliation plane. Local differences among islands (Figure 11) may be suggestive of late shallow local rotations due to a partial separation of the blocks along with the main joint system (Figures 5, 6, 7 and 12).

This hypothesis is validated by the observed variability of the joint system directions among the different rocks of the archipelago (Figure 12). The emerged rocks are bounded by a main joint system showing a striking correspondence with the expected Riedel shear components in the stress field generated by the transform fault (Figure 6). Sedimentary filling of some fractures also suggests the possibility that open fractures are loci for partial movement and rotations

The structure and morphology of the Atoba ridge allow making some hypotheses on the local causes affecting the different blocks. The Atoba Ridge is a push-up ridge linked to the step-overs of the northern side of the St. Paul transform System [7] (Maia et al, 2016). While such features are commonly observed at inflection points of active continental $[41,42,43,44,45]$, they are extremely rare in oceans being the Atoba the most representative case [7] and references therein.

The active uplift of the Atoba ridge is significant, being the most intense ongoing tectonism among the Brazilian territories [17]. Such a strong uplift rate implies the presence of gravitational instabilities because of the fast pressure-release undergoing in the shallow part of the ridge and resulting in detachments surfaces and block slumping (Figure 12) as attested by crack partial opening with various infillings (Figure 7). The presence of erosional surfaces, possibly marking the rhythmicity of the uplift (Campos et al., 2010) results in progressive unloading of the shallowest part of the ridge generating local (Figure 1). Moreover, uplift mainly interests mantle-derived rocks locally extremely olivine-rich which appears as the only lithological component of the entire ridge $[16,17,20,21]$. Intermediate-T hydration of mantle-derived rocks may result in enhanced buoyancy because of the volume expansion associated with the serpentinization process [46]. Serpentinization expansion may represent an internal push-up additional force to the disruption of the Atoba ridge's tip.

These factors may act as local causes superposed to far-field-controlled stresses responsible for the measured block rotation among the different rocks of the SPSPA.

\section{Conclusions}

The Atoba ridge uplift (St. Peter and St. Paul Archipelago) through the oceanic lithosphere impressed characteristics that registered the deformation mechanisms during the transition from ductile to brittle regime. The fracture analysis of the emerged abyssal peridotite of the SPSPA led us to conclude that:

$>$ The joints observed at the SPSPA are classified into four types: a) High-angle parallel joints of tectonic origin; b) Random direction joints formed by serpentinization expansion; c) Low-angle parallel joints of load release origin; and d) Open joints filled with limestone, sandstones, conglomerates and iron oxideshydroxides; 


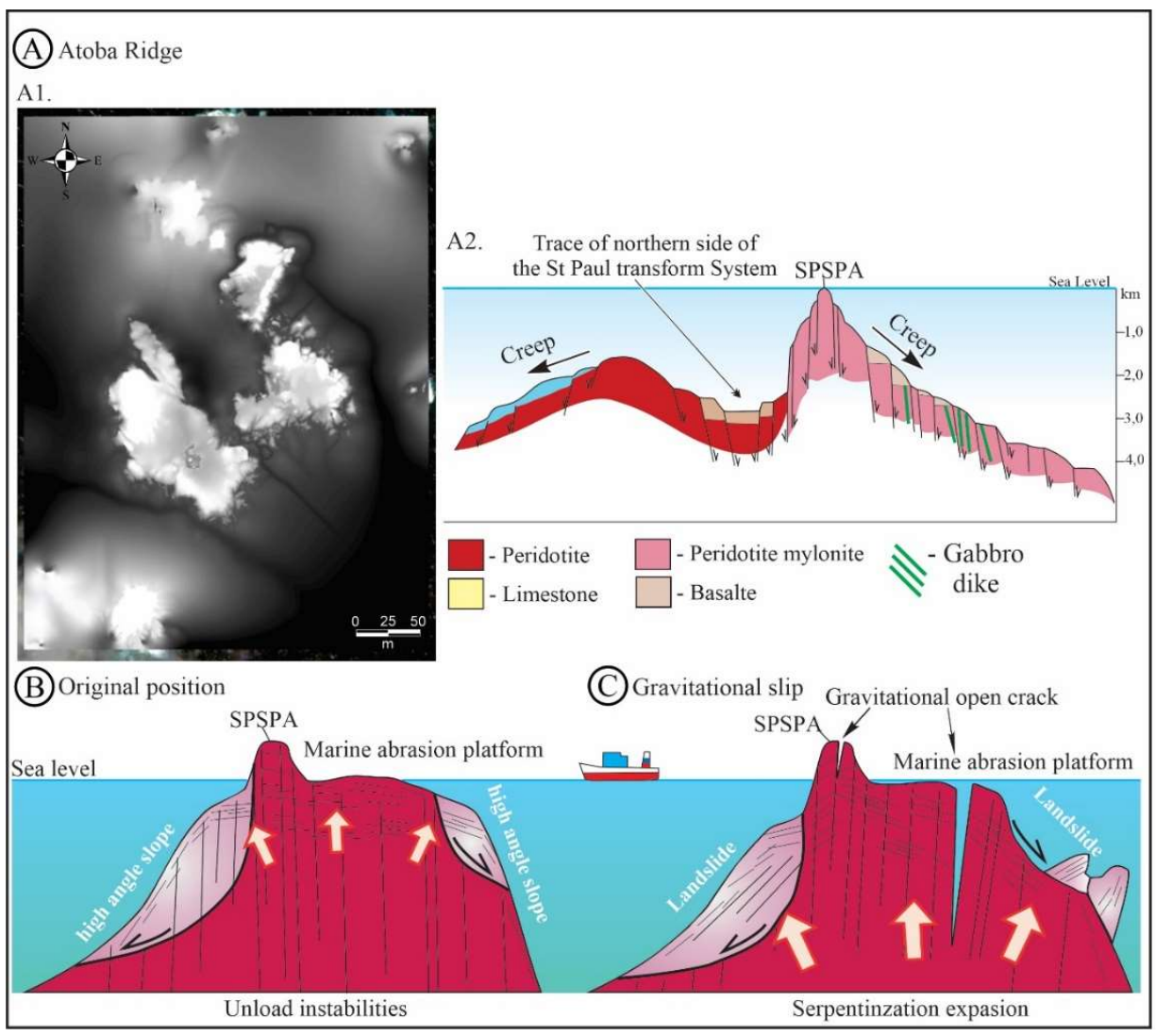

Figure 12: Submarine profile: A1) Topographic digital imagery by interpolation among surface and submarine topography show as shaded relief; A2) Atoba ridge profile according [16]; B and C) Schematic cross-section expressing the gravitational rockslide and fracture formation at the Saint Peter and Saint Paul Rocks. Gravitational instabilities and be generated by local shallow causes (unload pressure release) or deeper (volume expansion due to serpentinization). Vertical dimension not to scale.

$>$ The tectonic joints system show preferred directions of $332^{\circ} / 80^{\circ}$ (A1), $31^{\circ} / 57^{\circ}$ (B1) and $225^{\circ} / 37^{\circ}(\mathrm{C} 1)$. A1 and B1 form a conjugate system with NNW-SSE shortening direction and $\mathrm{C} 1$ is an extension joint;

$>$ The interpreted lineaments at the SPSPA show a direction of compression axes (N3.5oW) similar to the joint system;

$>$ The conjugate joint system is coherent with the existence of almost N-S compression. This stress agrees with the focal mechanism of the earthquakes that occurred close to the south of Atoba Ridge and with the published tectonic model for the Atoba ridge uplift;

$>$ The mylonitic foliation was generated by the St. Paul Transform Zone movement either related to the flowing mantle or by a contraction in restraining rocks;

$>$ The mylonitic foliations served as a zone of weakness for the beginning of the joint and serpentinization processes;

$>$ The rotation blocks after the mylonite foliation and the joint system formation is provoked by the North-South compression or by serpentinization expansion, gravitational rockslide and pull-apart fissures, concomitantly. 


\begin{abstract}
Author Contributions: Fieldwork, T.C., J. N., K.M. and L. B.; Conceptualization, T.C., L.B., M.M and D.B; Methodology, T.C, L.B and D.B; Data curation, T.C., L.B., M.M and D.B; Writing-original draft preparation, T.C.; Writing, T.C., L.B., D.B., M.M. and P.S; Review and editing, T.C, K.M, S.S, L.B, M.M, D.B, T.V., P.S. and E.F. All authors have read and agreed to the published version of the manuscript.
\end{abstract}

Funding: Please add: This research was funded by CNPq-National Resource Committee (Process 442805/2015-2), PETROBRAS - Petroleum of Brazil (Process RUMASPSP)

Institutional Review Board Statement: Not applicable.

Informed Consent Statement: Not applicable.

Data Availability Statement: Not applicable.

Acknowledgments: In this section, you can acknowledge any support given which is not covered by the author contribution or funding sections. This may include administrative and technical support, or donations in kind (e.g., materials used for experiments).

Conflicts of Interest: The authors declare no conflict of interest.

\title{
References
}

1. Dick, H. J., Fisher, R. L., Bryan, W. B. Mineralogical variability of the uppermost mantle along mid-ocean ridges. Earth and Planet. Sci. Lett. 1984, 69(1), 88-106.

2. Dick, H. J. B. Abyssal peridotites, very slow spreading ridges and ocean ridge magmatism. Geological Society, London, Special Publications, 1989, 42(1), 71-105.

3. Seyler, M., Lorand, J. P. Toplis M. J., and Godard G., Asthenospheric metasomatism beneath the mid-ocean ridge: Evidence from depleted abyssal peridotites, Geology, 2004, 32(4), 301-304.

4. Brunelli, D., Seyler, M., Cipriani, A., Ottolini, L., Bonatti, E. Discontinuous melt extraction and weak refertilization of mantle peridotites at the Vema lithospheric section (Mid-Atlantic Ridge). J. Petrol. 2006, 47(4), 745-771.

5. Warren, J. M. Global variations in abyssal peridotite compositions. Lithos, 2016, 248, 193-219.

6. Galindo-Zaldívar, J. Maldonado, A. Schreider, A. A.. Gorringe Ridge gravity and magnetic anomalies are compatible with thrusting at a crustal scale Geophys. J. Int. 2003, 153, Issue 3(1), 586-594, doi.org/10.1046/j.1365-246X.2003.01922.x

7. Maia M., Sichel, S., Briais, A., Brunelli, D., Ligi. M., Ferreira, N., Campos, T., Mougel, B., Brehme, I., Hémond, C., Motoki, A., Moura, D., Scalabrin, C., Pessanha, I., Eliane Alves, E., Ayres, A., Oliveira, P. Extreme mantle uplift and exhumation along a transpressive transform fault. Nature Geosci. Letters, 2016, 9, 619-623. doi.org/10.1038/ngeo2759

8. [Darwin, C. R. Journal of researches into the geology and natural history of the countries visited during the voyage of H.M.S. Beagle round the world. 1839

9. Darwin, C. R. Geological observations on the volcanic islands and parts of South America visited during the voyage of HMS "Beagle". 1891 doi.org/10.5962/bhl.title.61452

10. Renard, A.F. Peridotite von der St. Paul's lnsel im Atlantischen Ozean. Neues Jahrb Mineral Geol, 1879, 1(5), $390-394$.

11. Renard, A. -F. Description lithologique des récifs de Saint-Paul (Lat. $0^{\circ} 55^{\prime} 36^{\prime \prime}$ N. - Long. 29²2' 32"O). In H. Manceaux (Ed.), Extrait des Annales de la Société Belge de Microscopie 1882a, Vol. 1, p. 53). Bruxellees/Montagne de la Cour: H Manceuax.

12. Renard, A.-F. Report on the petrology of the rocks of St. Paul (Atlantic). Report on the scientific results of the voyage of H.M.S. Challenger during the years 1873-76 under the command of Captain Georges S. Nares and the late Captain Frank Tourle Thomson, Part I Narrative. Vol. II. H.M. Printed for Her Majesty's Stationery Office, Longmans \& Co. London.1882b 29, 1 Plate, 2(1).

13. Renard, A.F. A propos des roches de St.-Paul. Bulletin Des Séances de La Société Belge de Microscopie, 1883, IX(X), 165-178.

14. Murray, J., Renard, A.-F. Report on the scientific results of the voyage of H.M.S. Challenger during the years 1873-76 under the command of Captain Georges S. Nares and the late Captain Frank Tourle Thomson: Deep-Sea Deposits 1891, Vol.1. London: H.M. Governement.

15. Schilling, J. G., Hanan, B. B., McCully, B., Kingsley, D., Fontignie, D. Influence of the Sierra Leone mantle plume on the equatorial Mid-Atlantic. J. Geophys. Res., 1994, 99(B6), 12005-12028. doi.org/10.1029/94JB00337

16. Hékinian, R., Juteau, T., Gracia, E., Udintsev, G., Sichler, B., Sichel, S.E., Apprioual, R. Submersible observations of Equatorial Atlantic Mantle: The St. Paul Joint Zone region. Mar. Geophys. Res., 2000, 21, 529-560.

17. Campos, T.F.C., Bezerra, F.H.R., Srivastava, N.K., Vieira, M.M., Vita-Finzi, C. Holocene tectonic uplift of the St Peter and St Paul Rocks (Equatorial Atlantic), consistent with emplacement by extrusion. Marine Geol., 2010, 271, 177-186.

18. Yamaji, A., Sato K. Clustering of fracture orientations using a mixed Bingham distribution and its application to paleostress analysis from dike or vein orientations. J. Struc. Geol. 2011, 33, 1148-1157. doi.org/10.1016/j.jsg.2011.05.006

19. Yamaji, A. GArcmB Software Package User's Guide: Software for fiting mixed Bingham distribution to 3D orientation data. Division of Earth and Planet. Sci., 2016. Kyoto University, Japan 
20. Barão, L. M., Trzaskos, B., Angulo, R. J., de Souza, M. C. Deformation and structural evolution of mantle peridotites during exhumation on transform faults: A forced transition from ductile to brittle regime. J. Struc. Geol., 2020,133, 103981. doi.org/10.1016/j.jsg.2020.103981

21. Brunelli, D., Seyler, M. Asthenospheric percolation of alkaline melts beneath the St. Paul region (Central Atlantic Ocean). Earth and Planet. Sci. Lett., 2010, 289(3-4), 393-405.

22. Wolfe, C.J., Bergman, E.A., Solomon, S.C. Oceanic transform earthquakes with unusual mechanism or locations: relation to fault geometry and state of stress in the adjacent lithosphere. J. Geophys. Res., 1993, 98, 16187-16211. doi.org/10.1029/93JB00887

23. Melo, G. W. S., Nascimento, A. F.. Earthquake Magnitude Relationships for the Saint Peter and Saint Paul Archipelago, Equatorial Atlantic. Pure and Applied Geophy., 2018, 175(3), 741-756. doi.org/10.1007/s00024-017-1732-6

24. Angulo, R.J., de Souza, M.C., Campos, T.F.C., Bezerra, F.H.R., Fernandes, L.A., Giannini, P.C.F., Pitombo, F.B., Veiga, F.A. Evidence for late quaternary episodic uplift of the São Pedro and São Paulo Archipelago, Equatorial Atlantic. Quat. Int. 2013, 317, 102-111. doi.org/10.1016/j.quaint.2013.06.023.

25. Motoki, A., Sichel, S.E., Campos, T.F.C., Srivastava, N.K., Soares, R.S. Present-day uplift rate of the Saint Peter and Saint Paul Islets, Equatorial Atlantic Ocean. REM-Revista Escola de Minas, 2009, 62-3, 331-342.

26. Ryan, W.B.F., S.M. Carbotte, J.O. Coplan, S. O'Hara, A. Melkonian, R. Arko, R.A. Weissel, V. Ferrini, A. Goodwillie, F. Nitsche, J. Bonczkowski, and R. Zemsky Global Multi-Resolution Topography synthesis, Geochem. Geophys. Geosyst., 2009,10, Q03014. doi.org/10.1029/2008GC002332

27. Schilling,J. G., Hanan, B.B., McCully, B., Kingsley, D. \& Fontignie, D., 1994. Influence of the Sierra Leone mantle plume on the equatorial Mid-Atlantic Ridge: A Nd-Sr-Pb isotopic study. J. Geophys. Res. 1994, 99-B6, 12005-12028 https://doi.org/10.1029/94JB00337

28. Schilling J.G., Ruppel C., Davis A.N., Mccuiiy B., Tighe SA, Kingsley R.H., Lin, J. Thermal Structure of the Mantle Beneath The Equatorial Mid-Atlantic Ridge: Inferences From The Spatial Variation of Dredged Basalt Glass Compositions. J. Geophys. Res., 1995, 100(B6): 10057- 10076. doi.org/10.1029/95JB00668

29. Scheidegger, A.E. The significance of surface joints. Geophys. Surveys, 1985, 7: 259. https://doi.org/10.1007/BF01449545

30. Petite, J.P. Criteria for the sense of movement on fault surfaces in brittle rocks. J. Struc. Geol., 1987, 9, 597-608.

31. Ramsay, J.G. The crack-seal mechanism of rock deformation. Nature 1980, 284, 135-139. doi.org/10.1038/284135a0.

32. Logan, J.M., Friedman, M., Higgs, N., Dengo, C. and Shimamoto, T. Experimental studies of simulated gouge and their application to studies of natural zones. US Geological Survey, Open-file Report 791239, 1979, 305-343

33. Krantz, R.W. Multiple fault sets and three-dimensional strain: Theory and Application. J. Struc. Geol., 1988, 10, $225-237$. doi.org/10.1016/0191-8141(88)90056-9

34. Hancock, P.L. Brittle microtectonics: principles and practice. J. Struct. Geol., 1985, 7:437-457.

35. Hancock, P.L. Determining contemporary stress directions from neotectonic joint systems. Philos. Trans. R. Soc., 1991, 337, 2940.

36. Hancock, P.L. and Engelder, T. Neotectonic joints. Geol. Soc. Am. Bull. 1989, 101, 197-208.

37. Ramsay, J. G., Huber, M. I. The Techniques of Modern Structural Geology: Fold and Fracture. 1st Edition. Volume 2. 391 pages. Academic Press, London. 1987. ISBN-13: 978-0125769228

38. Caputo R.A. A comparison between joints and faults as brittle structures used for evaluation the stress field. Anales Tectonicae, 1991, 5:74-84.

39. Mandl, G. Rock Joints: The Mechanical Genesis. Springer softcover reprint of hardcover 1st ed. 2005, 219 pages. ISBN 978-3-54026457-6

40. Dunne W.M.; Hancock P.L. Palaeostress analysis of small-scale brittle structures. In Continental Deformation. Hancock P.L. (ed.) Oxford, Pergamom Press, 1994, pp 101-120.

41. Unsworth, M. J., P. E. Malin, G. D. Egbert, and J. R. Booker 1997. Internal structure of the San Andreas Fault at Parkfield, California. Geol., 1997, 25,359-362,

42. Burford, O., Harsh, P.W. Slip on the San Andreas fault in central California from alignment array surveys. Bull. Seismol. Soc. Am., 1980, 70-4, 1233-1261.

43. Garfunkel, Z., Zak, I., Freun, R., Active faulting in the Dead Sea rift. Tectonophys, 1981, 80-1, 1-26.

44. Goldfinger, C., Kulm. V.D., Yeats, R.S., Hummon, C., Huftile, G.J., Niem, A.R., McNeill, R.C. Oblique Strike-Slip Faulting of the Cascadia Submarine Fore-arc: The Daisy Bank Fault Zone off Central Oregon. AGU Geophysical Monograph, 1996, 96, 1-12.

45. McClay, K., Bonora, M. Analog models of restraining stepovers in strike-slip faults systems. Ameri. Associa. Petro. Geol. Bull. 2001, 85, 233-260

[46] Bonatti, E. Vertical tectonism in oceanic fracture zones. Earth and Planet. Sci. Lett., 1978, 37(3), 369-379. 